Izabela Pruchnicka-Grabias*

\title{
ZASTOSOWANIE MIAR MAKSYMALNEJ STRATY NA KAPITALE W BADANIU EFEKTYWNOŚCI FUNDUSZY HEDGINGOWYCH
}

\section{Wprowadzenie}

Fundusze hedgingowe jako szczególny rodzaj inwestycji wymagają zastosowania właściwych miar ich efektywności. Powszechne stosowanie odchylenia standardowego jako miary ryzyka przy ocenie działalności funduszy hedgingowych budzi niepokój ze względu zarówno na konieczność przyjęcia określonych założeń, jak i oparcie jego konstrukcji na średnim zakresie odchyleń. W artykule autorka przedstawia badania własne, dotyczące pomiaru efektywności funduszy hedgingowych za pomocą takich miar alternatywnych jak wskaźnik Calmara, Sterlinga i Burkego, które zostały przeprowadzone na podstawie danych z bazy Hedge Fund Research dla lat 2005-2011. Jest to przyczynek do dalszych badań poświęconych alternatywnym miarom efektywności inwestycji funduszy hedgingowych. Ich celem jest odpowiedź na pytanie, czy rzeczywiście alternatywne miary efektywności inwestycji stanowią bardziej adekwatne narzędzie pomiaru efektywności inwestycji funduszy hedgingowych niż tradycyjny wskaźnik Sharpe’a. Jak na razie, odpowiedź na to pytanie jest zaskakująco negatywna.

\section{Problemy metodologiczne pojawiające się w związku z pomiarem wyników inwestycyjnych funduszy hedgingowych}

Podstawowym problemem związanym $\mathrm{z}$ dokonywaniem badań nad rynkiem funduszy hedgingowych jest występująca niejednorodność i niekompletność baz

Szkoła Główna Handlowa w Warszawie, Kolegium Ekonomiczno-Społeczne. 
danych. W Unii Europejskiej za pomocą stosownej Dyrektywy ${ }^{1}$ obowiązującej od 22 lipca 2013 r. wprowadzono wymogi dotyczące obowiązkowej rejestracji większości funduszy hedgingowych i konieczności raportowania swoich wyników do baz danych, przy czym potrzebne będzie przynajmniej kilka, jeśli nie kilkanaście lat, by bazy danych rzeczywiście stały się kompletne i wystarczająco reprezentatywne do prowadzenia wiarygodnych badań. Obecnie w literaturze przedmiotu można spotkać wiele sprzecznych ze sobą wniosków dotyczących wyników inwestycyjnych funduszy hedgingowych i generowanego przez nie ryzyka, w zależności od zastosowanej bazy danych, przyjętej miary ryzyka czy założonego okresu badawczego ${ }^{2}$. Poza tym wspomniane regulacje dotyczą wyłącznie rynku unijnego. W Stanach Zjednoczonych nadal, pomimo wielu prób, nie udało się w całości wdrożyć regulacji dotyczących funduszy hedgingowych, a rynki tamtejsze są na tyle elastyczne, że od razu reagują, tworząc nowe wehikuły niepodlegające stworzonym regulacjom. Dodatkowo, nawet wdrożenie z sukcesem regulacji również na rynku amerykańskim, nie tylko unijnym, nie jest wystarczającą formułą rozwoju tych podmiotów. Od ostatniego kwartału 2013 r. obserwujemy stopniowy wzrost kapitału funduszy hedgingowych rejestrowanych na rynkach azjatyckich ${ }^{3}$. Jak widać, regulacje na jednym rynku wpływają na przenoszenie się funduszy hedgingowych w miejsca o bardziej liberalnych regulacjach, pozwalając ich zarządzającym na nieprzestrzeganie restrykcyjnych regulacji stworzonych w Unii Europejskiej. Z globalnego punktu widzenia stanowi to istotny problem, którego rozwiązanie w praktyce jest w zasadzie niemożliwe, przynajmniej $\mathrm{w}$ dającej się przewidzieć najbliżzzej przyszłości.

\section{Istota tradycyjnych miar efektywności}

Wśród standardowych sposobów oceny efektywności inwestycji można wyróżnić: wskaźnik Sharpe’a, wskaźnik Jensena oraz wskaźnik Treynora. Wskaźnik Sharpe’a można przedstawić w następującej postaci':

1 Directive 2011/61/EU of the of the European Parliament and of the Council of 8 June 2011 on Alternative Investment Fund Managers and amending Directives 2003/41/EC and 2009/65/EC and Regulations (EC) No. 1060/2009 and (EU) No. 1095/2010, “Official Journal of the European Union" 2011.

2 Zob. np. B. Liang, On the Performance of Hedge Funds, "Financial Analysts Journal" 1999, s. 72-85; T. Schneeweis, G. Martin, H. Kazemi, V. Karavas, The Impact of Leverage on Hedge Fund Risk and Return, "The Journal of Alternative Investments," 2005, Vol. 7, No. 4, s. 10-21; S. Titman, The leverage of hedge funds, "Finance Research Letters" 2010, Vol. 7, s. 2-7.

3 Zob. np. Hedge Fund Research Global Hedge Fund Industry Report - Fourth Quarter 2013; Hedge Fund Research Global Hedge Fund Industry Report - First Quarter 2014, https://www.hedgefundresearch.com/

4 W.F. Sharpe, The Sharpe ratio, "Journal of Portfolio Management" 1975, Vol. 21, No. 1, s. 49-58. 


$$
\text { Sharpe Ratio }=\frac{r_{i}^{d}-r_{f}}{\sigma\left(r_{i}\right)}
$$

gdzie:

Sharpe Ratio - wynik inwestycyjny z portfela aktywów $i$, $r_{i}^{d}$ - wartość średnia stopy zwrotu z portfela aktywów $i$, $\sigma\left(r_{i}\right)$ - odchylenie standardowe stóp zwrotu z portfela aktywów $i$, $r_{f}$ - wolna od ryzyka stopa procentowa.

Zaznaczyć należy, że wskaźnik Sharpe’a stanowi względną miarę efektywności polityki inwestycyjnej i służy do porównania ze sobą kilku czy większej liczby funduszy hedgingowych, a nie do oceny efektywności inwestycji pojedynczego funduszu, podobnie jak wskaźnik Sortino czy Treynora. Wskaźnik Sharpe’a jest najczęściej podawanym wskaźnikiem pomiaru wyników funduszy hedgingowych na ich stronach internetowych ${ }^{5}$, jak i w literaturze przedmiotu ${ }^{6}$. Jednocześnie w literaturze przedmiotu znajdują się dowody na to, że stosujący go nie biorą pod uwagę, iż jest on przybliżoną miarą efektywności, podatną na występowanie znacznych i znaczących błędów szacunkowych ${ }^{7}$.

Kolejny z wymienionych, wskaźnik Jensena, definiujemy następująco:

$$
J R=\left(r_{i}^{d}-r_{f}\right)-\left(r_{i p}^{d}-r_{f}\right) \beta_{i}
$$

gdzie:

$\beta_{i}$ - wrażliwość zmian stóp zwrotu generowanych przez dany fundusz w porównaniu z rynkiem, za który należy przyjąć określony portfel referencyjny (np. indeks), $r_{i p}^{d}$ - średnia stopa zwrotu z portfela rynkowego.

Wadą wskaźnika Jensena jest możliwość dokonania sztucznego zawyżenia dochodów generowanych przez fundusz dzięki zastosowaniu przez zarządzających dźwigni finansowej.

Wskaźnik Treynora można przedstawić w następującej postaci:

$$
\text { Treynor Ratio }=\frac{r_{i}^{d}-r_{f}}{\beta_{i}}
$$

5 Zob. np. strony internetowe funduszy Credit Suisse First Boston Group.

6 Zob. np. N. Chan, M. Getmansky, S. Haas, A. Lo, Do Hedge Funds Increase Systemic Risk?, "Economic Review" 2006, 91(4), s. 49-80, za: Derivatives Pricing, Hedge Funds and Term Structure Models, red. G.N. Gregoriou, R. Pascalau, Palgrave, Macmillan, Hampshire 2011, s. 10-11.

7 A.W. Lo, The Statistics of Sharpe Ratios, "Financial Analysts Journal" 2002, No. 7-8, s. 36-50.

8 W. Breuer, M. Guertler, F. Schuhmacher, Portfopiomanagement I - Theoretische Grundlagen und praktische Anwendungen, Gabler, Wiesbaden 2004, za: M. Eling, F. Schuhmacher, Does the choice of performance measure influence the evaluation of hedge funds?, "Journal of Banking and Finance" 2007, Vol. 31, s. 7. 
Wskaźniki Treynora i Jensena są właściwe do zastosowania w sytuacji, gdy tylko część kapitału inwestycyjnego jest lokowana w fundusze hedgingowe.

\section{Rodzaje alternatywnych miar efektywności}

Przedmiotem niniejszego artykułu nie jest szczegółowe przedstawianie alternatywnych miar efektywności, lecz zwrócenie uwagi na istnienie innych metod oceny efektywności niż tradycyjnie stosowane. Można je podzielić na kilka następujących grup: - miary maksymalnej straty, wśród których należy wymienić wskaźnik Calmara, Sterlinga, Burke'go $)^{9}$,

- miary oparte na wartości narażonej na ryzyko, takie jak np. nadwyżkowa stopa zwrotu ponad wartość narażoną na ryzyko (VaR), warunkowy wskaźnik Sharpe’a czy zmodyfikowany wskaźnik Sharpe’a ${ }^{10}$,

- miary oparte na niższych momentach cząstkowych, tj. m.in. wskaźnik Omega, Sortino Kappa ${ }^{11}$,

- miary stworzone na wzór wskaźnika Sharpe’a, lecz uwzględniające skośność oraz kurtozę rozkładu stóp zwrotu' ${ }^{12}$

- miary oparte na wyższych momentach cząstkowych określające potencjał zysku (upside potential ratio) ${ }^{13}$,

- analiza dopasowania danych (Data Envelopment Analysis, DEA), będąca podejściem nieparametrycznym opartym na programowaniu liniowym w celu pomiaru nakładów i wyników ${ }^{14}$.

9 T.W. Young, Calmar Ratio: a smoother tool, "Futures" 1991, Vol. 20, No. 1, s. 40; G. Burke, A sharper Sharpe ratio, "Futures" 1994, Vol. 23, No. 3, s. 56; L.N. K, Getting a handle on true performance, "Futures" 1996, Vol. 25, No. 1, s. 44-46.

${ }^{10}$ M. Eling, F. Schuhmacher, Does the choice of performance measure influence the evaluation of hedge funds?, "Journal of Banking and Finance" 2007, No. 31, s. 2635-2637.

11 W.V. Harlow, Asset Allocation in a Downside-Risk Framework, "Financial Analysts Journal" 1991, No. 9-10, s. 28-40; P.D. Kaplan, J.A. Knowles, Kappa: A Generalized Downside Risk - Adjusted Performance Measure, "Morningstar Associates and York Hedge Fund Strategies" 2004, No. 1, s. 1-17.

${ }^{12}$ K. Dowd, Beyond Value at Risk. The New Science of Risk Management, John Wiley \& Sons, New York 1998, za: Hedge Funds. Insights in Performance Measurement, Risk Analysis, and Portfolio Management, red. G.N. Gregoriou, G. Huebner, N. Papageorgiou, F. Rouah, John Wiley \& Sons Inc., Hoboken 2005, s. $549-550$.

${ }^{13}$ F.A. Sortino, R. van der Meer, A. Plantiga, The Dutch triangle, "Journal of Portfolio Management" 1999, Vol. 26, s. 50-58.

${ }^{14}$ M. Eling, Performance Measurement of Hedge Funds Using Data Envelopment Analysis, "Working Papers on Risk Management and Insurance" 2006, No. 25, University of St. Gallen, s. 2-29. 
Wspólną cechą wszystkich miar maksymalnej straty na kapitale jest branie pod uwagę stopy zwrotu wygenerowanej powyżej stopy zwrotu wymaganej przez inwestora, za którą przyjmuje się wolną od ryzyka stopę procentową. Wskaźnik Calmara uwzględnia maksymalną stratę na kapitale możliwą do wygenerowania w badanym okresie, natomiast wskaźnik Sterlinga bierze pod uwagę średnią stratę z N największych strat wygenerowanych na kapitale. Niewątpliwą zaletą wskaźnika Sterlinga w porównaniu ze wskaźnikiem Calmara jest zmniejszenie wrażliwości wyników na ewentualne wysokie straty pojawiające się bardzo rzadko. Jednocześnie stanowi to jednak jego wadę w kontekście zastosowania do pomiaru wyników funduszy hedgingowych, które mogą uzyskiwać atrakcyjne stopy zwrotu przez dłuższy okres, po czym wygenerować dla inwestora choćby nawet pojedynczą, ale znaczną stratę, której wskaźnik efektywności Sterlinga nie weźmie pod uwagę. Jeśli chodzi o wskaźnik Burkego, ten również cechuje się niską wrażliwością na generowanie maksymalnych strat na kapitale. Wskaźniki Calmara, Sterlinga i Burkego w porównaniu do tradycyjnej miary efektywności przedstawionej przez Sharpe’a cechuje większa wrażliwość na generowane ujemne stopy zwrotu. Ze względu na wyjątkowe parametry stóp zwrotu generowanych przez fundusze hedgingowe, miary te wydają się bardziej adekwatne do zastosowania w ich wypadku niż wskaźnik Sharpe’a. Jak widać, nie ma jednej idealnej miary efektywności w tej grupie wskaźników, a wyniki badań przedstawione w tabeli 1 oraz tabeli 2 pokazują, że uzyskane wartości różnią się między sobą. Dlatego też rozsądne wydać by się mogło stworzenie rankingu funduszy hedgingowych opartego na średniej arytmetycznej wszystkich trzech wskaźników.

Wszystkie wyżej wymienione miary efektywności biorą pod uwagę pewien tylko aspekt ryzyka (np. VaR, momenty cząstkowe, skośność czy kurtozę), której to wady nie ma analiza DEA. Została ona po raz pierwszy zaproponowana do pomiaru efektywności sektora publicznego, gdy mierzono związek pomiędzy wyprodukowanymi towarami i usługami (wynikami) oraz zużytymi zasobami (nakładami). W kontekście funduszy hedgingowych $\mathrm{M}$. Eling ${ }^{15}$ proponuje jako nakłady przyjąć różne miary ryzyka, a jako wyniki - stopy zwrotu uzyskane przez fundusz. W efekcie przeprowadzenia procesu optymalizacji uzyskujemy wynik, który można uznać za miarę efektywności. Jednocześnie nie można uznać DEA za metodę właściwą w każdym wypadku, gdyż zastosowanie poszczególnych miar ryzyka często zależy od preferencji inwestora, a M. Eling nie dostarczył w swoich badaniach dowodu na fakt, że DEA pozwala na stworzenie bardziej wiarygodnego rankingu funduszy hedgingowych niż pozostałe miary efektywności oparte na wybranych elementach ryzyka.

15 Ibidem, s. 2, 26. 


\section{Możliwości zastosowania wybranych miar alternatywnych do pomiaru wyników funduszy hedgingowych}

Literatura przedmiotu podkreśla zalety miar efektywności inwestycji opartych na wygenerowanej maksymalnej stracie na kapitale w porównaniu do tradycyjnego podejścia opartego na odchyleniu standardowym stóp zwrotu ${ }^{16}$. Tego rodzaju podejście jest bliższe inwestorom, którzy w większym stopniu koncentrują się na stratach aniżeli na potencjalnych zyskach. Miary te są popularne w praktyce, zwłaszcza jeśli chodzi o aktywnie zarządzane fundusze CTA, prawdopodobnie dlatego, że bardziej przemawiają do inwestorów, obejmując potencjalne niebezpieczeństwo poniesienia straty, a nie ogólny zakres zmienności rynku. Jest to zgodne z behawioralną teorią finansów, a konkretnie z wnioskami D. Kahnemana i A. Tversky'ego ${ }^{17}$, w myśl których radość inwestora wynikająca $\mathrm{z}$ wygenerowania zysku jest mniejsza niż jego żal po osiągnięciu straty o tej samej wartości. Dla przykładu, W.V. Harlow stwierdza, że optymalizacja oparta na miarach ryzyka rozumianego w ujęciu negatywnym pozwala na tworzenie strategii o zrealizowanych stopach zwrotu mających mniejszą ekspozycję na ryzyko rozumiane jako strata aniżeli ta oparta na wariancji ${ }^{18}$. M. Eling i F. Schuhmacher proponują zastąpienie wskaźnika Sharpe’a przez inne miary efektywności, gdy stopy zwrotu $\mathrm{z}$ badanej inwestycji nie mają rozkładu normalnego ${ }^{19}$, a tak jest w wypadku stóp zwrotu generowanych przez fundusze hedgingowe. Jedną z grup miar odnoszących się do koncentracji na ryzyku rozumianym w sposób negatywny, a konkretnie na wygenerowanych stratach, są wskaźniki maksymalnej straty na kapitale. Odnoszą one nadwyżkę stopy zwrotu ponad wolną od ryzyka stopę procentową do różnie rozumianych, w zależności od przyjętej miary, strat poniesionych na kapitale w ustalonym horyzoncie czasowym. W obrębie tej grupy wskaźników można wyróżnić wskaźnik Calmara, Sterlinga oraz Burky’ego. I tak w szczególności, wskaźnik Calmara, przedstawiany jest następująco ${ }^{20}$ :

$$
\mathrm{CR}=\frac{r_{i}^{d}-r_{f}}{-M D_{i}}
$$

\footnotetext{
16 W.V. Harlow, op.cit., s. $28-40$.

17 D. Kahneman, A. Tversky, Prospect theory: an analysis of decision under risk, "Econometrica" 1979, Vol. 47, No. 2, s. 263-292.

18 W.V. Harlow, op.cit., s. 28-40.

${ }^{19}$ M. Eling, F. Schuhmacher, op.cit., s. 2632-2647.

20 T.W. Young, op.cit., s. 40. Zob. M. Eling, F. Schuhmacher, op.cit., s. 6.
} 
gdzie:

$r_{f}$ - stopa procentowa wolna od ryzyka,

$r_{i}^{d}$ - średnia wartość stopy zwrotu $\mathrm{z}$ aktywów $i$,

$\mathrm{MD}_{i}$ - najniższa stopa zwrotu $\mathrm{z}$ aktywów i w założonym horyzoncie czasowym.

Jak widać, wskaźnik Calmara uwzględnia najniższą stopę zwrotu z aktywów w przyjętym okresie. Jego zaletą jest uwzględnienie najgorszego scenariusza w przeszłości, ale jednocześnie wadę stanowi duża wrażliwość na generowanie przypadkowych stóp zwrotu spowodowanych przez mało prawdopodobne zdarzenia. Wprowadzenie znaku minus do mianownika sprawia, że maksymalizacja efektywności inwestycji następuje wraz ze wzrostem wskaźnika, czyli optymalna efektywność występuje, gdy:

$$
\mathrm{CR} \rightarrow \max
$$

Aby zmniejszyć wspomnianą wrażliwość wskaźnika Calmara, można zastosować wskaźnik Sterlinga, w wypadku którego bierze się pod uwagę średni poziom N maksymalnych ujemnych stóp zwrotu.

Wskaźnik Sterlinga definiowany jest następująco ${ }^{21}$ :

$$
\mathrm{SR}=\frac{r_{i}^{d}-r_{f}}{\frac{1}{N} \sum_{j=1}^{N}\left(-M D_{i j}\right)}
$$

Tutaj również maksymalizacja efektywności inwestycji następuje wraz ze wzrostem wskaźnika, a zatem z optymalną efektywności inwestycji mamy do czynienia, gdy:

$$
S R \rightarrow \max
$$

W wypadku wskaźnika Burky’ego odnosi się nadwyżkę stopy zwrotu do pierwiastka kwadratowego z sumy kwadratów $\mathrm{N}$ najniższych stóp zwrotu wygenerowanych w zadanym horyzoncie czasowym.

Matematyczna postać wskaźnika Burky’ego to ${ }^{22}$ :

$$
\mathrm{BR}=\frac{r_{i}^{d}-r_{f}}{\sqrt[2]{\sum_{j=1}^{N} M D_{i j}^{2}}}
$$

Optymalną efektywność uzyskujemy, tak jak w poprzednich wypadkach, gdy:

$$
\mathrm{BR} \rightarrow \max
$$

\footnotetext{
${ }^{21}$ L.N. Kestner, op.cit., s. 44-46; M. Eling, F. Schuhmacher, op.cit., s. 6.

${ }^{22}$ G. Burke, op.cit., s. 56; M. Eling, F. Schuhmacher, op.cit., s. 6.
} 
Jeśli porównamy konstrukcję przedstawionych wskaźników do tradycyjnej miary ryzyka, za którą uznaje się wskaźnik Sharpe’a (wzór 1) widać, że w wypadku tego drugiego nadwyżka stopy zwrotu ponad stopę wolną od ryzyka odnoszona jest do ryzyka mierzonego odchyleniem standardowym, a zatem rozumianego $\mathrm{w}$ aspekcie zarówno pozytywnym, jak i negatywnym. W jego wypadku również dąży się do maksymalizacji wskaźnika.

\section{Empiryczna weryfikacja miar maksymalnej straty jako narzędzia pomiaru wyników inwestycyjnych funduszy hedgingowych skorygowanych o ryzyko}

W artykule przeprowadzono badania efektywności funduszy hedgingowych przy użyciu wyżej wymienionych miar maksymalnej straty na kapitale w danym horyzoncie czasowym i porównano $\mathrm{z}$ wynikami uzyskanymi za pomocą tradycyjnej miary efektywności. Na tej podstawie utworzono rankingi poszczególnych strategii funduszy hedgingowych i zmierzono współczynniki korelacji liniowej Pearsona pomiędzy badanymi wskaźnikami. Analizy prowadzą do wniosku, że wyniki pomiaru efektywności funduszy hedgingowych rozumianej w zgodzie $\mathrm{z}$ tradycyjnym podejściem H. Markowitza jako wypadkowa zysku i ryzyka oraz pomiaru efektywności funduszy hedgingowych za pomocą miar nowoczesnych odnoszących zysk do maksymalnej straty na kapitale wygenerowanej w wybranym horyzoncie czasowym, wykazują się wysokim stopniem zbieżności. Badania przeprowadzono na podstawie danych z bazy Hedge Fund Research dla horyzontu czasowego od 2005 r. do marca 2011 r. Niniejsze opracowanie zawiera badania pilotażowe dotyczące zasadności szerszego zastosowania alternatywnych miar ryzyka do badania efektywności funduszy hedgingowych. Przyjęto założenie, że miesięczna stopa procentowa wolna od ryzyka wynosi $0,28 \%{ }^{23}$. Wyniki badań zawarto w tabeli 1.

Badane wskaźniki (tabela 1) są miarami względnymi, co sprawia, że komentowanie tych wielkości jako osobnych wyników nie ma sensu. Dlatego sporządzono

\footnotetext{
${ }^{23}$ Jako minimalną akceptowalną przez inwestora stopę zwrotu wprowadzono wolną od ryzyka stopę procentową, za którą przyjęto oprocentowanie dziesięcioletnich amerykańskich obligacji skarbowych pod koniec okresu badawczego, tj. na koniec kwietnia 2011 r. (3,32\%). W literaturze nie ma jednoznacznego poglądu na temat, czy przyjęta stopa procentowa wolna od ryzyka powinna być z końca badanego okresu, z jego początku, czy też zmieniana w trakcie badań. Zob. np. A. Bernardo, O. Ledoit, Gain, loss and asset pricing, "Journal of Political Economy" 2000, Vol. 108, No. 1, s. 144-172. Źródło danych: http://www.treasury.gov/resource-center/data-chart-center/interest-rates/Pages/TextView.aspx?data=yieldYear\&year=2011, dostęp 5.11.2014.
} 
ich rankingi w tabeli 2. Cechują się one wysokim stopniem podobieństwa i jeśli się różnią, to o jedną, maksymalnie dwie pozycje. Wyjątek stanowi ranking dla współczynnika Burkego dla $\mathrm{n}=10$. W tym wypadku strategia Macro z początkowych dwóch pozycji spadła aż na pozycję siódmą. Natomiast strategia Emerging Markets osiągnęła pozycję pierwszą, a nie trzecią czy czwartą, jak w wypadku pozostałych wskaźników. Może to świadczyć o generowaniu przez fundusze stosujące tę strategię atrakcyjnych dodatnich stóp zwrotu w porównaniu do pozostałych, lecz w wyjątkowych sytuacjach pojawiają się prawdopodobnie ekstremalne ujemne stopy zwrotu, na które wskaźnik Burkego jest niewrażliwy.

Tabela 1. Wartości wskaźników Sharpe’a, Calmara, Sterlinga i Burkego dla strategii stosowanych przez fundusze hedgingowe

\begin{tabular}{|l|c|c|c|c|c|c|}
\hline \multicolumn{1}{|c|}{ Strategia } & $\begin{array}{c}\text { Wskaźnik } \\
\text { Sharpe'a }\end{array}$ & $\begin{array}{c}\text { Wskaźnik } \\
\text { Calmara }\end{array}$ & $\begin{array}{c}\text { Pięcio- } \\
\text { okresowy } \\
\text { wskaźnik } \\
\text { Sterlinga }\end{array}$ & $\begin{array}{c}\text { Dziesięcio- } \\
\text { okresowy } \\
\text { wskaźnik } \\
\text { Sterlinga }\end{array}$ & $\begin{array}{c}\text { Pięcio- } \\
\text { okresowy } \\
\text { wskaźnik } \\
\text { Burkego }\end{array}$ & $\begin{array}{c}\text { Dziesięcio- } \\
\text { okresowy } \\
\text { wskaźnik } \\
\text { Burkego }\end{array}$ \\
\hline Merger Arbitrage & 0,216981 & 0,118154 & 0,160875 & 0,197196 & 0,048743 & 0,044314 \\
\hline Macro & 0,210884 & 0,079409 & 0,113 & 0,144711 & 0,070163 & 0,014666 \\
\hline Relative Value & 0,178571 & 0,043611 & 0,073121 & 0,12106 & 0,028059 & 0,025669 \\
\hline Emerging Markets & 0,168449 & 0,037354 & 0,077426 & 0,104578 & 0,031483 & 0,05794 \\
\hline Event Driven & 0,140097 & 0,035405 & 0,062917 & 0,089586 & 0,025432 & 0,018433 \\
\hline Equity Hedge & 0,08209 & 0,02326 & 0,036801 & 0,051259 & 0,015315 & 0,018085 \\
\hline Multistrategy & 0,074766 & 0,015481 & 0,032089 & 0,049949 & 0,011435 & 0,006601 \\
\hline $\begin{array}{l}\text { Fixed Income } \\
\text { Convertible Arbitrage }\end{array}$ & 0,074286 & 0,014991 & 0,029618 & 0,046604 & 0,011603 & 0,040767 \\
\hline Equity Market Neutral & $-0,04938$ & $-0,01393$ & $-0,01653$ & $-0,02493$ & $-0,00713$ & $-0,0074$ \\
\hline Short Bias & $-0,14124$ & $-0,04957$ & $-0,068$ & $-0,0835$ & $-0,02986$ & $-0,02288$ \\
\hline
\end{tabular}

Źródło: Obliczenia własne.

Tabela 2. Ranking strategii stosowanych przez fundusze hedgingowe dla kryterium wskaźnika Sharpe’a, Sterlinga, Calmara i Burkego

\begin{tabular}{|c|l|l|l|l|l|l|}
\hline $\begin{array}{c}\text { Wskaźniki/ } \\
\text { Lp. }\end{array}$ & $\begin{array}{c}\text { Wskaźnik } \\
\text { Sharpe'a }\end{array}$ & $\begin{array}{c}\text { Wskaźnik } \\
\text { Calmara }\end{array}$ & $\begin{array}{r}\text { Pięcio- } \\
\text { okresowy } \\
\text { wskaźnik } \\
\text { Sterlinga }\end{array}$ & $\begin{array}{r}\text { Dziesięcio- } \\
\text { okresowy } \\
\text { wskaźnik } \\
\text { Sterlinga }\end{array}$ & $\begin{array}{l}\text { Pięcio- } \\
\text { okresowy } \\
\text { wskaźnik } \\
\text { Burkego }\end{array}$ & $\begin{array}{l}\text { Dziesięcio- } \\
\text { okresowy } \\
\text { wskaźnik } \\
\text { Burkego }\end{array}$ \\
\hline 1 & $\begin{array}{l}\text { Merger } \\
\text { Arbitrage }\end{array}$ & Macro & Macro & Macro & Macro & $\begin{array}{l}\text { Emerging } \\
\text { Markets }\end{array}$ \\
\hline 2 & Macro & $\begin{array}{l}\text { Merger } \\
\text { Arbitrage }\end{array}$ & $\begin{array}{l}\text { Merger } \\
\text { Arbitrage }\end{array}$ & $\begin{array}{l}\text { Merger } \\
\text { Arbitrage }\end{array}$ & $\begin{array}{l}\text { Merger } \\
\text { Arbitrage }\end{array}$ & $\begin{array}{l}\text { Merger } \\
\text { Arbitrage }\end{array}$ \\
\hline 3 & Relative Value & $\begin{array}{l}\text { Emerging } \\
\text { Markets }\end{array}$ & Relative Value & Relative Value & $\begin{array}{l}\text { Emerging } \\
\text { Markets }\end{array}$ & $\begin{array}{l}\text { Fixed Income } \\
\text { Convertible } \\
\text { Arbitrage }\end{array}$ \\
\hline
\end{tabular}




\begin{tabular}{|c|l|l|l|l|l|l|}
\hline $\begin{array}{c}\text { Wskaźniki/ } \\
\text { Lp. }\end{array}$ & \multicolumn{1}{|c|}{$\begin{array}{c}\text { Wskaźnik } \\
\text { Sharpe'a }\end{array}$} & $\begin{array}{c}\text { Wskaźnik } \\
\text { Calmara }\end{array}$ & $\begin{array}{c}\text { Pięcio- } \\
\text { okresowy } \\
\text { wskaźnik } \\
\text { Sterlinga }\end{array}$ & $\begin{array}{c}\text { Dziesięcio- } \\
\text { okresowy } \\
\text { wskaźnik } \\
\text { Sterlinga }\end{array}$ & $\begin{array}{c}\text { Pięcio- } \\
\text { okresowy } \\
\text { wskaźnik } \\
\text { Burkego }\end{array}$ & $\begin{array}{c}\text { Dziesięcio- } \\
\text { okresowy } \\
\text { wskaźnik } \\
\text { Burkego }\end{array}$ \\
\hline 4 & $\begin{array}{l}\text { Emerging } \\
\text { Markets }\end{array}$ & Relative Value & $\begin{array}{l}\text { Emerging } \\
\text { Markets }\end{array}$ & $\begin{array}{l}\text { Emerging } \\
\text { Markets }\end{array}$ & Relative Value & Relative Value \\
\hline 5 & Event Driven & Event Driven & Event Driven & Event Driven & Event Driven & Event Driven \\
\hline 6 & Equity Hedge & Equity Hedge & Equity Hedge & $\begin{array}{l}\text { Fixed Income } \\
\text { Convertible } \\
\text { Arbitrage }\end{array}$ & Equity Hedge & Equity Hedge \\
\hline 7 & Multistrategy & Multistrategy & Multistrategy & Multistrategy & $\begin{array}{l}\text { Fixed Income } \\
\text { Convertible } \\
\text { Arbitrage }\end{array}$ & Macro \\
\hline 9 & $\begin{array}{l}\text { Fixed Income } \\
\text { Convertible }\end{array}$ & $\begin{array}{l}\text { Fixed Income } \\
\text { Convertible } \\
\text { Arbitrage }\end{array}$ & $\begin{array}{l}\text { Fixed Income } \\
\text { Convertible } \\
\text { Arbitrage }\end{array}$ & Equity Hedge & Multistrategy & Multistrategy \\
\hline 10 & $\begin{array}{l}\text { Equity Market } \\
\text { Neutral }\end{array}$ & $\begin{array}{l}\text { Equity Market } \\
\text { Neutral }\end{array}$ & $\begin{array}{l}\text { Equity Market } \\
\text { Neutral }\end{array}$ & $\begin{array}{l}\text { Equity Market } \\
\text { Neutral }\end{array}$ & $\begin{array}{l}\text { Equity Market } \\
\text { Neutral }\end{array}$ & $\begin{array}{l}\text { Equity Market } \\
\text { Neutral }\end{array}$ \\
\hline
\end{tabular}

Źródło: Opracowanie własne.

Tabela 3. Współczynniki korelacji liniowej Pearsona pomiędzy poszczególnymi wskaźnikami efektywności mierzącymi wyniki poszczególnych strategii stosowanych przez fundusze hedgingowe ${ }^{\star}$

\begin{tabular}{|l|c|c|c|c|c|c|}
\hline & Sharpe & Calmar & $\begin{array}{c}\text { Sterling dla } \\
\mathrm{N}=5\end{array}$ & $\begin{array}{c}\text { Sterling dla } \\
\mathrm{N}=10\end{array}$ & $\begin{array}{c}\text { Burke dla } \\
\mathrm{N}=5\end{array}$ & $\begin{array}{c}\text { Burke dla } \\
\mathrm{N}=10\end{array}$ \\
\hline Sharpe & 1 & 0,92 & 0,96 & 0,99 & 0,96 & 0,77 \\
\hline Calmar & 0,92 & 1 & 0,99 & 0,98 & 0,92 & 0,67 \\
\hline Sterling dla $\mathrm{N}=5$ & 0,96 & 0,99 & 1 & 0,99 & 0,93 & 0,73 \\
\hline Sterling dla $\mathrm{N}=10$ & 0,99 & 0,98 & 0,99 & 1 & 0,93 & 0,74 \\
\hline Burke dla $\mathrm{N}=5$ & 0,96 & 0,92 & 0,93 & 0,93 & 1 & 0,98 \\
\hline Burke dla $\mathrm{N}=10$ & 0,77 & 0,67 & 0,73 & 0,74 & 0,98 & 1 \\
\hline
\end{tabular}

* zaokrąglenie do dwóch miejsc po przecinku.

Źródło: Opracowanie własne.

Jak wynika z danych zgromadzonych w tabeli 3 , istnieje wysoka korelacja pomiędzy wskaźnikiem Sharpe’a a alternatywnymi miarami efektywności inwestycji. W większości wypadków kształtuje się ona na poziomie przynajmniej 0,92 - z jednym wyjątkiem. Korelacja pomiędzy współczynnikiem Sharpe’a i Burkego liczonym dla $\mathrm{n}=10$ jest nieznacznie niższa i wynosi 0,77 . Biorąc pod uwagę współczynniki korelacji pomiędzy pozostałymi wskaźnikami, można powiedzieć, że są one również wysokie, przy czym współczynnik Burkego dla $\mathrm{n}=10$ cechuje najniższa korelacja nie tylko ze wskaźnikiem Sharpe’a, lecz także z alternatywnymi miarami efektywności 
inwestycji. Może to być wynikiem tego, że pozostaje on niewrażliwy na generowanie przez fundusz wysokich wartości pojedynczych ujemnych stóp zwrotu.

\section{Podsumowanie}

Przedstawione wyniki badań pokazują, że wprowadzanie nowoczesnych miar ryzyka nie musi poprawiać pomiaru efektywności inwestycji, mimo że tradycyjne miary ryzyka krytykowane są za brak spełniania podstawowych założeń leżących $\mathrm{u}$ ich podstaw. Badania mają charakter wstępny, więc należy być ostrożnym w formułowaniu wniosków w sposób jednoznaczny. Zapewne ich wyniki mogłyby stanowić źródło dla dalszego poszukiwania najbardziej adekwatnych miar efektywności funduszy hedgingowych, a gdyby znalazły potwierdzenie dla innych okresów badawczych, prowadziłyby do postawienia pytania, czy przypadkiem nie przecenia się znaczenia alternatywnych miar efektywności.

\section{Bibliografia:}

Bernardo A., Ledoit O., Gain, loss and asset pricing, "Journal of Political Economy" 2000, Vol. 108, No. 1.

Breuer W., Guertler M., Schuhmacher F., Portfopiomanagement I - Theoretische Grundlagen und praktische Anwendungen, Gabler, Wiesbaden 2004.

Burke G., A sharper Sharpe ratio, "Futures" 1994, Vol. 23, No. 3.

Chan N., Getmansky M., Haas S., Lo A., Do Hedge Funds Increase Systemic Risk?, "Economic Review" 2006, No. 91(4).

Derivatives Pricing, Hedge Funds and Term Structure Models, red. G.N. Gregoriou, R. Pascalau, Palgrave, Macmillan, Hampshire 2011.

Directive 2011/61/EU of the of the European Parliament and of the Council of 8 June 2011 on Alternative Investment Fund Managers and amending Directives 2003/41/EC and 2009/65/EC and Regulations (EC) No. 1060/2009 and (EU) No. 1095/2010, "Official Journal of the European Union" 2011.

Dowd K., Beyond Value at Risk. The New Science of Risk Management, John Wiley \& Sons, New York 1998.

Eling M., Schuhmacher F., Does the choice of performance measure influence the evaluation of hedge funds?, "Journal of Banking and Finance" 2007, Vol. 31. 
Eling M., Performance Measurement of Hedge Funds Using Data Envelopment Analysis, "Working Papers on Risk Management and Insurance" 2006, No. 25, University of St. Gallen.

Harlow W.V., Asset Allocation in a Downside - Risk Framework, "Financial Analysts Journal" 1991, No. 9-10.

Hedge Fund Research Global Hedge Fund Industry Report - First Quarter 2014, https:// www.hedgefundresearch.com/

Hedge Fund Research Global Hedge Fund Industry Report - Fourth Quarter 2013, https:// www.hedgefundresearch.com/

Hedge Funds. Insights in Performance Measurement, red. G.N. Gregoriou, Huebner G., Papageorgiou N., Rouah F., Risk Analysis, and Portfolio Management, John Wiley \& Sons Inc., Hoboken 2005.

http://www.treasury.gov/resource-center/data-chart-center/interest-rates/Pages/TextView. aspx?data $=$ yieldYear\&year $=2011$

Kahneman D., Tversky A., Prospect theory: an analysis of decision under risk, "Econometrica" 1979, Vol. 47, No. 2.

Kaplan P.D., Knowles J.A., Kappa: A Generalized Downside Risk - Adjusted Performance Measure, "Morningstar Associates and York Hedge Fund Strategies" 2004, No. 1.

Kestner L.N., Getting a handle on true performance, "Futures" 1996, Vol. 25, No. 1.

Liang B., On the Performance of Hedge Funds, "Financial Analysts Journal" 1999.

Lo A.W., The Statistics of Sharpe Ratios, "Financial Analysts Journal" 2002, No. 7-8.

Schneeweis T., Martin G., Kazemi H., Karavas V., The Impact of Leverage on Hedge Fund Risk and Return, "The Journal of Alternative Investments" 2005, Vol. 7, No. 4.

Sharpe W.F., The Sharpe ratio, "Journal of Portfolio Management" 1998, Vol. 21, No. 1.

Sortino F.A., van der Meer R., Plantiga A., The Dutch triangle, "Journal of Portfolio Management" 1999, Vol. 26.

Titman S., The leverage of hedge funds, "Finance Research Letters" 2010, Vol. 7.

Young T.W., Calmar Ratio: a smoother tool, "Futures" 1991, Vol. 20, No. 1.

\section{Application of Maximum Capital Loss Measures in Research on Hedge Funds Effectiveness}

The paper presents research on hedge funds efficiency with such measures as Calmar ratio, Sterling ratio and Burke ratio carried out using the data from Hedge Fund Research database for 2005-2011. The aim of the study is to answer the question whether alternative efficiency measurs are really more adequate 
for assessing the efficiency of hedge fund investments. So far, the answer to this question is surprisingly negative.

Keywords: effectiveness, hedging funds, Sharpe ratio

\section{L'application des mesures de perte maximale du capital dans la recherche sur l'efficacité des fonds de couverture}

Le document présente les recherches sur l'efficacité des fonds de couverture avec l'utilisation des mesures telles que le ratio de Calmar, le ratio de Sterling et le ratio de Burke. Les données pour les années 2005-2011 proviennent de la base de données de Hedge Fund Research. L'objectif de l'étude est de déterminer si les mesures d'efficacité alternatives sont vraiment plus adéquates pour évaluer l'efficacité des investissements de type de «fonds de couverture». Jusqu'à présent, la réponse à cette question est étonnamment négative.

Mots clés: l'efficacité, les fonds de couverture, le ratio de Sharpe

\section{Использование мер максимального убытка в исследовании эффективности хеджевых фондов}

Статья включает анализ эффективности хедж-фондов, проведенный при использовании таких мер, как коэффициент Кальмара, отношение Стерлинга и коэффициент Берка. Исследование проводилось на основе данных Hedge Fund Research за период 2005-2011 гг. Цель статьи - ответ на вопрос являются ли альтернативные показатели эффективности более подходящими для оценки эффективности инвестиций хедж-фондов. Пока, к удивлению, ответ на этот вопрос оказывается негативным.

Ключевые слова: эффективность, хедж-фонды, коэффициент Шарпа 
